\title{
Raw Earth Construction Perspectives in Italy: An Overview Through the Rehabilitations of Casa Fenu in Villamassargia, Sardinia, and Casa di Teresa in Casalincontrada, Abruzzo
}

\section{Perspectivas de construcción con tierra cruda en Italia:}

Aspectos generales a través de de las rehabilitaciones de la Casa Fenu en Villamassargia, Cerdeña, y de la Casa de Teresa en Casalincontrada, Abruzos

\section{Perspectivas de construção em terra crua em Itália: Uma perspectiva geral através da reabilitação da Casa Fenu em Villamassargia, Sardenha, e da Casa di Teresa em Casalincontrada, Abruzo}

Keywords $\mid$ Palabras clave $\mid$ Pallaviras chave

Italian vernacular architecture, Contemporary earth building, Participatory approach, Field-training, Sustainable local development

Arquitectura vernácula italiana, Edificios de tierra contemporáneos, Enfoque participativo, Formación sobre el terreno, Desarrollo local sostenible

Arquitectura vernacular italiana, Construção contemporânea com terra, Abordagem participativa, Formação de campo, Desenvolvimento local sustentável

\author{
Abstract $\mid$ Resumen | Resumo
}

A detailed analysis of the rehabilitation processes of two publicly owned buildings in Sardinia and Abruzzo is taken as a basis for describing the background, difficulties and possible future developments of raw earth as a building material in Italy. Earthen construction techniques, despite a rich tradition and extensive documentation, are still considered outdated, and their use today requires a fortunate confluence of contextual factors. Archival research, literature review and a study of manuals were coupled with an examination of urban plans and public policies, as well as interviews with experts and stakeholders. This multi-approach research shows that there is a strong need to appropriate traditional knowledge so as to translate local skills into viable solutions able to meet today's needs. The key issue may be investment in training and dissemination. The mindset of the artisan, that of the homo faber (Sennet 2008), needs to be more widely associated with action toward sustainable local development.

Un análisis detallado de los procesos de rehabilitación de dos edificios públicos en Cerdeña y los Abruzos se utiliza para describir los antecedentes, las dificultades y la posible evolución futura de la tierra cruda como material de construcción en Italia. Las técnicas de construcción con tierra, a pesar de existir una rica tradición y una exhaustiva documentación, se siguen considerando obsoletas y requieren una feliz confluencia de factores contextuales para ser utilizadas hoy en día. La investigación en archivos, el análisis bibliográfico y el estudio de manuales se combinó con el examen de los planes urbanísticos y las políticas públicas, así como con entrevistas a expertos y partes implicadas. El enfoque múltiple de esta investigación demuestra que existe una gran necesidad de adoptar los conocimientos tradicionales para convertir las 
habilidades locales en soluciones viables que puedan dar respuesta a los requisitos actuales. El problema principal puede ser la inversión en formación y divulgación. Debería haber más gente que asocie la mente de artesano, del "homo faber" (Sennet 2008), con la acción a favor del desarrollo local sostenible.

Uma análise detalhada dos processos de reabilitação de dois edifícios públicos na Sardenha e Abruzo é utilizada para descrever o contexto, dificuldades e possíveis desenvolvimentos futuros da terra crua como material de construção em Itália. As técnicas de construção com terra, apesar de serem uma tradição rica e extensamente documentada, ainda são consideradas ultrapassadas e requerem uma confluência privilegiada de factores contextuais para serem utilizadas hoje em dia. A investigação de arquivos, a revisão bibliográfica e o estudo de manuais foram associados ao exame de planos urbanos e políticas públicas, assim como entrevistas com peritos e investidores. Esta investigação multiabordagem mostra que existe uma forte necessidade de apropriação dos conhecimentos tradicionais, de forma a traduzir as competências locais em soluções viáveis que possam satisfazer as necessidades actuais. A questão chave pode ser o investimento em formação e divulgação. São necessárias mais pessoas que associem a mente de artesão, do "homo faber" (Sennet 2008), à acção para o desenvolvimento local sustentável.

\section{Introduction}

The use of raw earth has received strong support in recent years, gaining relevance on the international scene. But regulatory difficulties, limited trust, a lack of specialized skills among designers and builders, and limited availability of approved materials still generate reticence to the pursuit of projects for the recovery of earthen structures or for new construction, with sociocultural consequences for the communities that inhabit and own them. This situation can lead to opposite albeit complementary phenomena of abandonment and gentrification.

This article sets out from an analysis of successful recovery stories concerning two earthen buildings in Italy: Casa Fenu (2005-2008), a large complex $\left(1,110 \mathrm{~m}^{2}\right.$ of covered project area) in the historic center of Villamassargia, Sardinia, and Casa di Teresa (2008-2015), a small house $\left(58 \mathrm{~m}^{2}\right)$ in Casalincontrada, Abruzzo. The former was restored by a contractor and the latter by an extensive worksite/workshop. The two case studies were chosen as representative of the resurgence of the use of earth in Italy, enriched over the years by numerous initiatives from regions, municipalities, and individuals. They reflect a determination to set good examples and to promote knowledge and awareness, along with the commitment of communities to preserving their earthen heritage and the associated traditional building techniques.

Primary and secondary data were combined with an integral approach, considering the restorations as interconnected, not just in their technical and material aspects but also in their social and intangible value.

Our paper starts with a review of raw-earth construction in Sardinia and Abruzzo. An analysis of the recovery of the two buildings follows. Our discussion critically examines the social, historical, spatial and legislative contexts for the stakeholders and their interactions, the role of the local communities, and also the subsequent impacts on those communities, focusing on the positive local effects of these restorations. Our conclusion reflects on the current situation in the rehabilitation of earthen architecture in Italy.

\section{Raw earth, a perspective from Sardinia and Abruzzo}

The use of raw earth in Sardinia dates back to the Nuragic period, i.e. 800-500 B.C., and persisted through the ages, with particular growth during the Spanish period and the rise of a "raw brick culture" in the early 20th century (Bertagnin 1999: 251). Earthen construction techniques are found in both urban and rural areas in the island's southern plains. They concern almost all building types, most of which revolve around a courtyard (Garau 2004: 187). In response to economic needs, the prevalent technique was that of unfired brick, locally called ladiri (derived from the Latin later, -is, meaning "brick"). With a widely available raw material, the maist'e muru (master masons) would make bricks by hand during fallow periods in the agricultural cycle, when a workforce was available and the fields could be used to let the bricks dry in the 
sun. Traditionally they used arrabbiaticcio, soil compacted through agricultural overuse but which was optimal for construction. It was not until the early 20th century that proper workshops producing unfired bricks began to spread, standardizing the process and materials. Their products mainly targeted urban markets.

In Abruzzo, the spread of earthen houses, known as case a terra or a massune or pinciaie, coincided with the re-appropriation of the countryside by farmers on the abolition of feudalism in the 19th century (Conti 2004: 24). But the growth of housing demand was not matched by an increase in production, which made the use of earth for self-building the only available option, "a parsimonious way of understanding living, (...) a building logic reduced to the essential" in the words of Gianfranco Conti (Albanesi 2012).

Constructing buildings was a cooperative act for peasant families: a kind of "time bank" was set up, with mutual exchange of labor. Mud and water were mixed using animal power while women were responsible for making the massoni, loaf-like blocks of earth and straw. After a night of curing, these blocks were laid side by side and at a $45^{\circ}$ angle (appearing as a herringbone pattern in façades) in rings so as to form a monolithic structure that works by compression, and then cut with a shovel.

The geographer Osvaldo Baldacci described this as "a spontaneous product of nature and intelligence, expressing a relationship that was elementary but not primitive" (Baldacci 1958). Earthen houses were built mainly in isolated rural areas, on ridges and hilltops.

After the Second World War, with the abandonment of the countryside, urbanization and suburbanization, and the economic boom, the earthen construction sector went into crisis in both regions. New buildings were inserted into the traditional fabric of towns without planning, disregarding both traditional designs and materials. Earth as a material was increasingly associated with poverty, difficult living conditions and backwardness, and was deemed incapable of denoting affluence (Conti 2004: 36). The abandonment of local construction techniques and traditional buildings led to the abandonment of traditional crafts, with the loss of about $50 \%$ of the earthen heritage in Sardinia and $88 \%$ in Abruzzo $^{1}$ within a few decades (Garau 2004: 190-191).

In the late 20th century, an increasing need arose for a systematic and urgent recovery of earthen heritage to help strengthen the identity of rural areas, linked to the knowledge handed down by older inhabitants and builders. Among the public initiatives that have marked the resurgence of raw earth in Sardinia and Abruzzo are respectively the rehabilitation of the Casa Fenu complex in Villamassargia (Fig. 1) by Ignazio Garau² (1949-2018), and that of Casa di Teresa in Casalincontrada (Fig. 2) by Gianfranco Conti. ${ }^{3}$
The two buildings have been turned into an eco-museum and an information and exhibition space respectively. The interventions were carried out with the aim of providing tangible examples of good practice to start bottom-up regeneration processes.

Figure1: Historic centre of the medieval town of Villamassargia, in which $79 \%$ of the buildings are in ladiri. The Casa Fenu complex is marked in red. Figure 2: Earth houses tour in and around Casalincontrada. The Casa di Teresa is marked in red (CEDTerra)
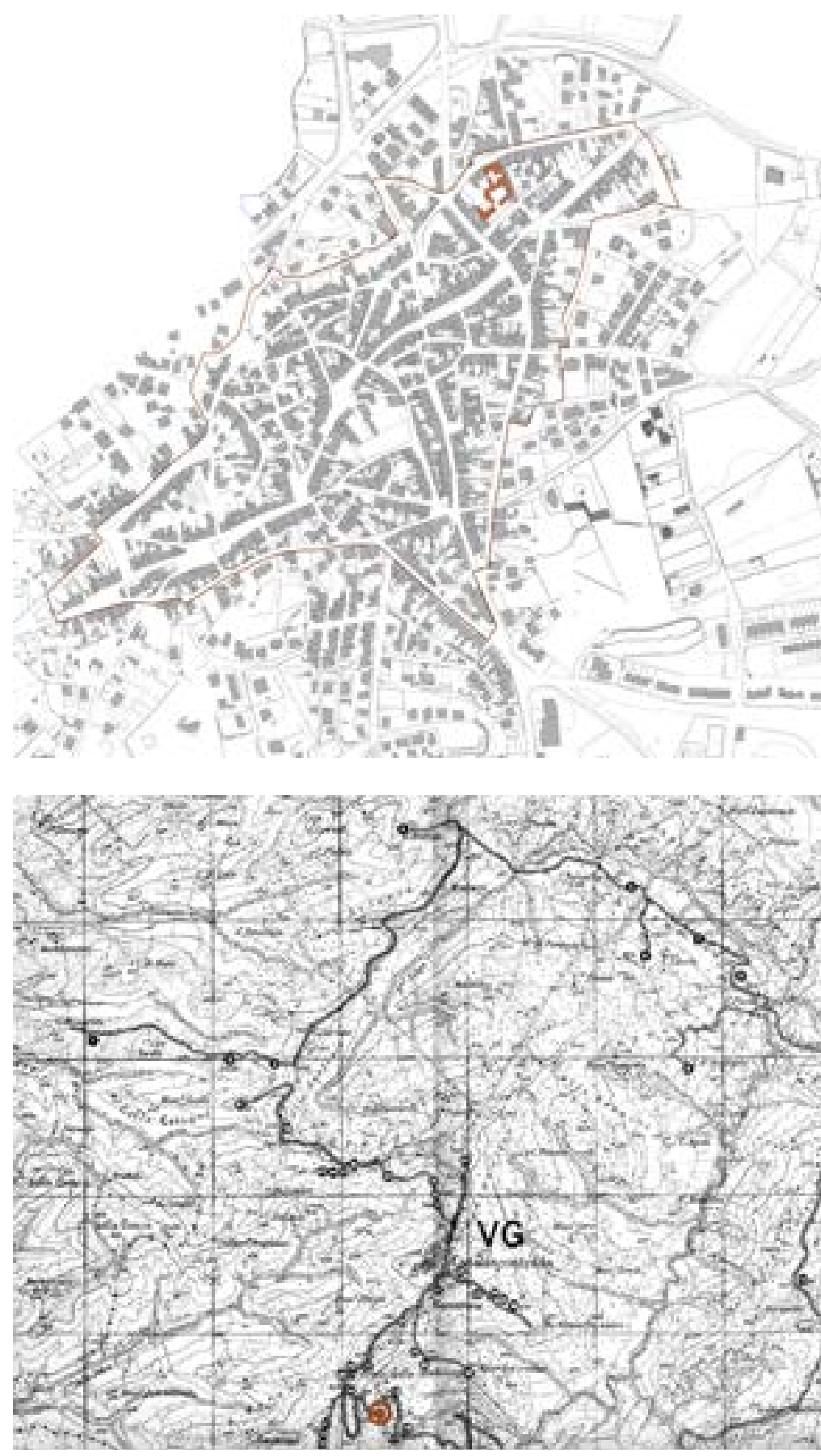


\section{Research methodology}

Our research was carried out between 2017 and 2021, as part of a broader investigation of case studies on European earthen buildings. In order to cover both new building and renovation, as well as different construction techniques and countries, 30 professionals were chosen according to their social and technical approach. On the basis of their availability and an analysis of the documentation they submitted, seven were selected: professionals with sound building know-how who use earth not only occasionally but place it at the center of their work, and who help to enhance its value and propagate its proper use. Among them were the architects Ignazio Garau and Gianfranco Conti.

The choice of buildings to be analyzed was the result of a joint appraisal. Consideration was given to architectural qualities and the ways in which techniques were used, and also to the buildings' functions and clients, with preference given to public or communal uses.

Our research methodology centered on face-to-face encounters, personal knowledge, experimentation and hands-on experience. Primary data were obtained from unstructured interviews, informal conversations with inhabitants, on-site observation and interviews with the main stakeholders in the projects, including public servants and advocates of raw-earth construction.

Further data were drawn from architects' archives (including site photographs, project drawings, technical reports and bills of quantities) (Conti 2008; Garau 2003), and from reviewing the literature, such as traditional construction manuals.

The projects were described in detail, with a previously unavailable in-depth analysis of earthen techniques (Bocci 2018). Project drawings were updated to describe the asbuilt situation.

\section{Casa Fenu}

Originally at the heart of a large farm of about 250 hectares, the family-owned Casa Fenu complex combines a dwelling with the functional needs of rural husbandry, with a sequence of three mixed-use courtyards connected by arched portals of fired brick (Fig. 3).

The entrance courtyard (I) is accessible through a covered hallway and represents the old residential core of the complex, with a "cellular house on the road with a courtyard behind and a plot of extended depth" (Sanna and Atzeni 2009: 27) - and its later extensions.

The ox yard (II) was the center of the complex, with a portico for sheltering animals and storing materials (Fig. 4).
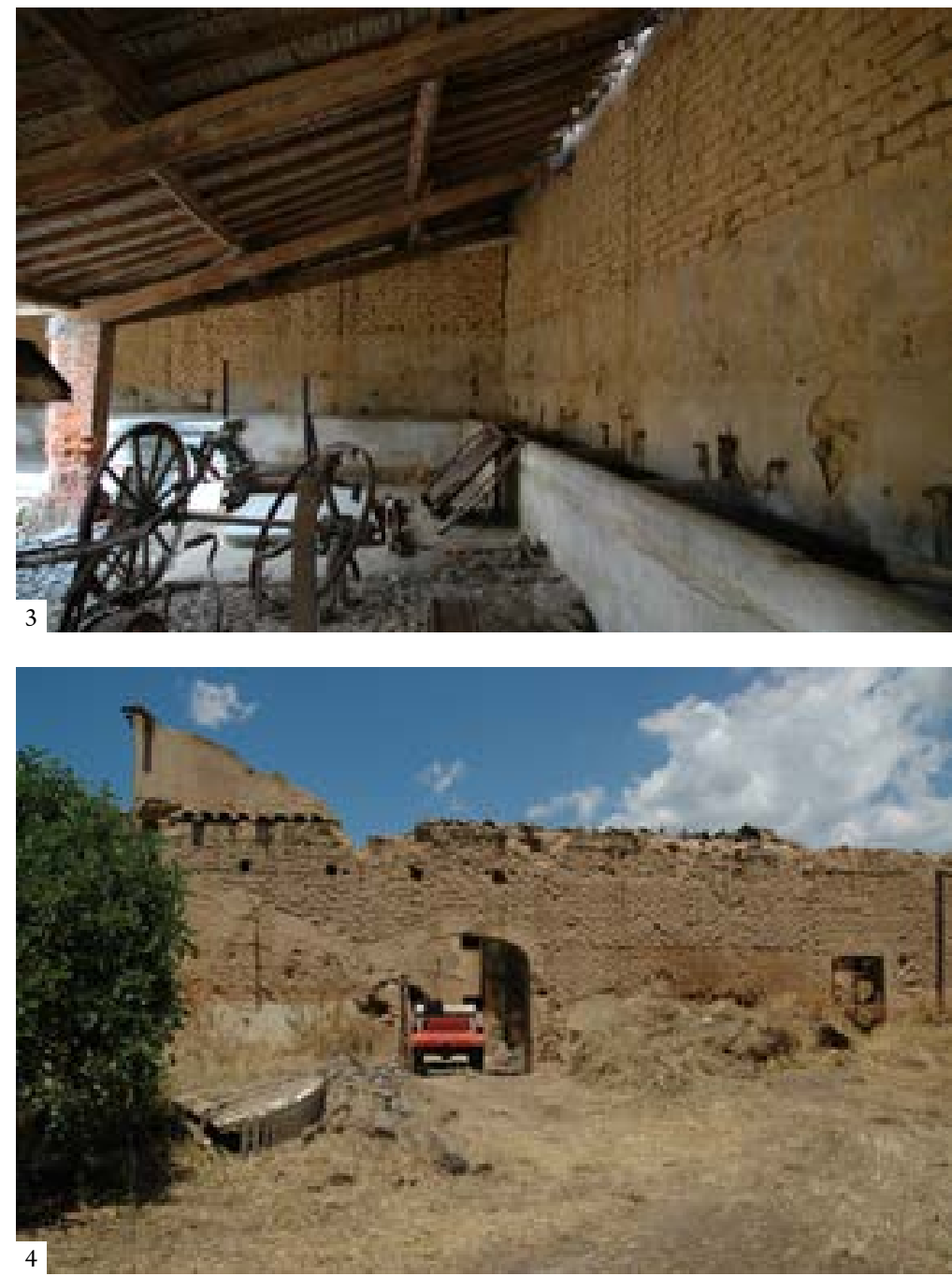

Figure 3: Outer walls of the oxen courtyard (II) in 2005 (Ignazio Garau)

Figure 4: The arch between courts I and II in 2005 (Ignazio Garau)

The smaller courtyard (III) was used for storage and originally gave access to animals and foodstuffs through a portal opening onto the road beyond the buildings that now surround it.

The stone and unfired-brick dwelling (A), dating from 1850 , originally had one story. The main entrance leads directly into the rooms of the house, mediating between the courtyard and the street according to a recurring sequence of "street/house/courtyard/annexes" (Sanna and Atzeni 2009: 39) Toward the courtyard was a loggia as a filter space - an essential component for bioclimatic regulation (Garau 2004: 188). As usual in Sardinia, openings are small, partly to keep out heat.

In the early 20 th century the complex underwent a major renovation. The main building was modified on urban models. The result was a hybridization with the palattu type: a stately house with symmetrical, regular-sized openings in the façade in a classical style, and a central accessway (Garau 2004: 188). The use of plaster and the 
incorporation of iron, fired-brick, and reinforced concrete elements also date from this period (Bertagnin 1999: 253). A bomb shelter was added in 1942 . The latest changes were made after the war, with a further extension of courtyard I and the replacement of some of the wooden flooring.

The expropriation of the farm's land in 1952 led to the decline of the complex, which was abandoned in the late 1960s. After forty years without maintenance, the roofs were falling apart, with a generalized spread of damp. Leaks and runoff had eroded the bricks and mortar and caused swelling, cracks, and detachment of the plaster layer.

After detailed surveys, in 1999 the complex was acquired by the municipality of Villamassargia for rehabilitation. The project envisaged the creation of a venue for "sustainable tourism" as well as for local people, with exhibitions of handicrafts from the Cixerri area, cultural workshops, and training facilities.

Faithful to the Sardinian tradition of hybridization with new technologies (Garau 2004: 194), the architect Ignazio Garau resisted the preconceived idea of "authenticity" in historic centers (which usually means copying traditional forms and techniques) in favor of evolution. As recommended by Vitruvius, Garau attempted to show that there can be a fruitful continuity between old craftsmen and modern builders, and that traditional materials can help reconnect with the "materiality of doing" (Achenza 2009; Garau 2005; Sennett 2008).

In his design Garau emphasized both the disorientation caused by the intricate sequence of courtyards and their multiple prospects, with no one perspective prevailing aspects inherent to Sardinian tradition. He also took the liberty to introduce variations and even to somewhat modify the layout of the complex, enhancing the usability of its spaces. Restoration work was made legible through the use of modern techniques and materials (Achenza 2009).

The restoration was based on different approaches in each part of the complex (Figs. 5 and 6); raw earth was used even in partially or completely rebuilt parts.

An integral, philological restoration of the house was made in courtyard I, based on traditional materials and construction techniques. Diagnostic investigations were carried out after removing plaster and renders. To reestablish structural integrity, steel ties were installed
Figure 5: Demolition and reconstruction plan. The demolition is marked in yellow and the new construction in red

Figure 6: Project plan, ground floor.

Courtyard I: A) exhibition rooms and tourist agency; B) storerooms; C) tasting rooms; D) Villa Fenu; 1) portal and entrance hall to the courtyard;2) main entrance; 3) connection to Villa Fenu.

Courtyard II: E1) cafeteria and E2) kitchens; F) exhibition area Courtyard III: G) workshop and laboratories; $\mathrm{H}$ ) conference room. Red: ladiri masonry; black: concrete; dark grey: stone masonry; grey: fired bricks and hollow bricks
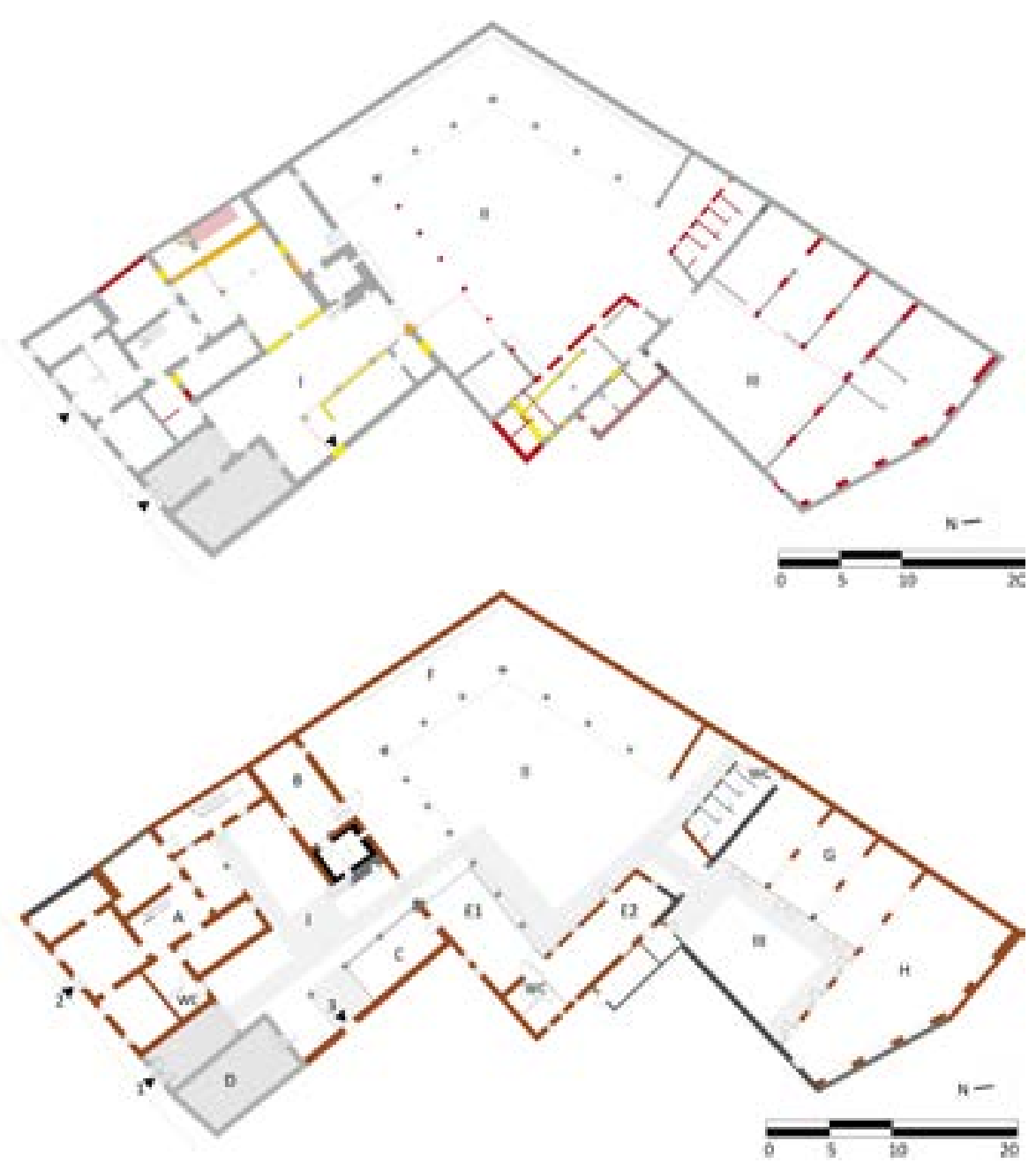
between opposite walls. Damaged wall portions were demolished and rebuilt with new ladiri (Fig. 7) measuring $10 \times 20 \times 40 \mathrm{~cm}$, made by hand with a mix of earth and fibers and laid on an earth, lime, and sand mortar bed. Minimum requirements for ladiri were established, such as dimensional stability and compressive strength. Deteriorated masonry surfaces were restored by removing loose parts, reinforcing with wooden sticks or filling with brick flakes and a mixed mortar of natural hydraulic lime, slaked lime, and sand, as well as by applying a mixture of earth and natural fibers in thin layers. The most delicate parts, such as plinths, cornerstones, doorposts, jambs, lintels, and roof-beam bearings, were strengthened with fired bricks (Fig. 8).

The portico and the buildings around courtyard II were reconstructed, with the addition of further buildings for equipment rooms and toilets.

Given their advanced state of decay, the remaining structures around courtyard III were demolished and reconstructed using ladiri. Fourteen arches (spanning about $2.5 \mathrm{~m}$ ) in four parallel walls were built with unfired bricks (Fig. 9). Fired bricks were also used at certain points to counteract the thrust and to support the roof trusses (Fig. 10)

A plaster made of earth, sand, and lime, plus natural fibers such as hay and straw, was applied on all walls. This was rendered with slaked lime and sand and finished with a smooth coat of long-aged slaked lime. The interior walls were limewashed, with color from natural earth pigments. The exterior walls were finished with two coats of a breathable, weather-resistant mixture of slaked lime, mineral additives, natural earths and oxides (Fig. 11).

The restored and new buildings were given reinforced concrete foundations and borders, external drainage, and crawl spaces, along with reinforced concrete screeds under the cocciopesto (made with crushed brick and aerial lime mortar), ceramic stoneware, and fired-brick floor tiles. Most of the intermediate floors of the buildings by courtyard I, built in 1947 with iron girders and hollow clay blocks or reinforced slabs, were rebuilt using solid fir beams.

The roof structure was rebuilt with solid fir beams in the original configuration, while in the buildings by courtyard III the trusses were formed with laminated glulam beams. The roofing combines industrial and natural materials (Fig. 12). In the outdoor areas, the cobblestones were taken up and reused (Fig. 13). Irregular slabs of Serrenti trachyte were laid dry on the main paths.

The timeframe for the works increased due to the contractor being replaced and a further survey being drawn up. The new contractor also took charge of ladiri production. The restoration work was completed in 2008 and Casa Fenu was inaugurated in 2009 (Figs. 14-16). The
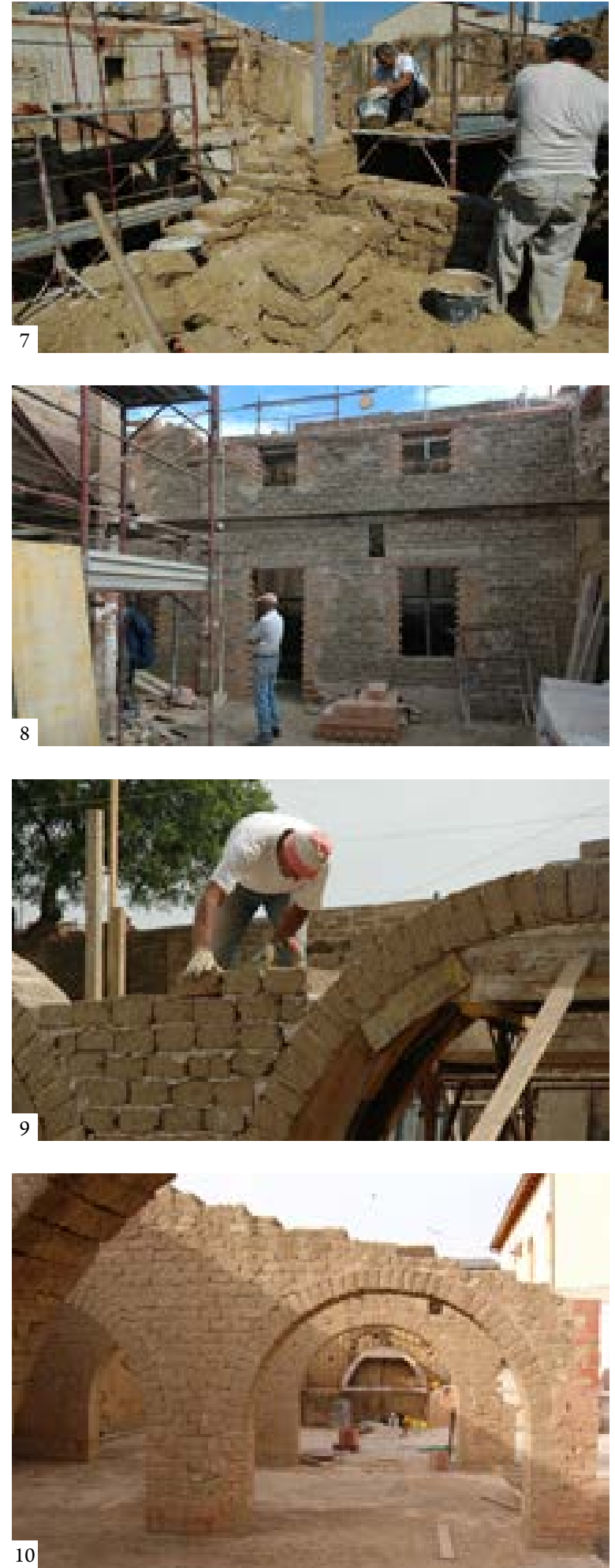

Figure 7: In the reconstruction work of building B, the reuse of original ladiri in good condition was frequent. The earth derived from the demolition, heterogeneous and with spurious materials, was not reused within the construction site, but was instead reused to fill the land where the earth used for the new bricks was extracted from. (Ignazio Garau)

Figure 8: The openings were consolidated: reveals and lintels were installed, sometimes with a new element on the inner side, or fired brick platbands, replacing the eroded or fractured bricks (Ignazio Garau)

Figure 9: Laying of ladiri in the construction of the portion of the wall between two arches (Ignazio Garau)

Figure 10: View through the arches of courtyard III (Ignazio Garau) 

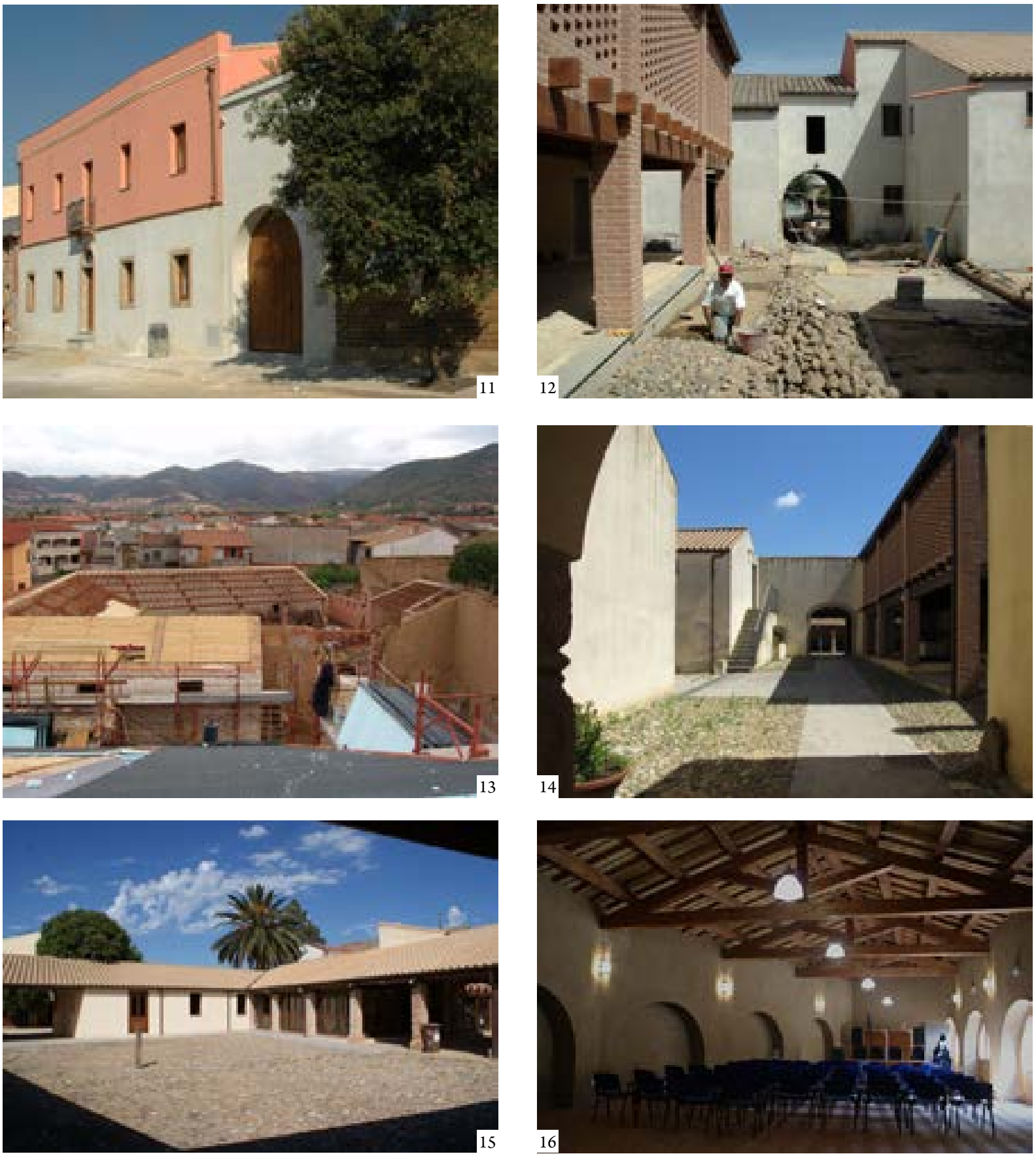

Figure 11: The colour of the main façade was chosen to match the shades found in other buildings in Via Santa Maria (Ignazio Garau)

Figure 12: Various stages in the construction of roofs: reed mats above the battens, non-woven fabric and EPS foam panels with a bituminous sheathing, curved tiles laid on lime mortar (Ignazio Garau)

Figure 13: The laying surface of the pavement was adjusted to ensure adequate slopes for water drainage, and a subflooring of stones, gravel, sand and cement was laid before the replacement of the cobblestones (Ignazio Garau)

Figure 14: Courtyard I as seen from the entrance hall (1): on the left the staircase leading to building B, on the right building C made of fired bricks on the second floor, while glass curtain walls enclose the rooms on the ground floor (Ignazio Garau)

Figure 15: The oxen courtyard (II) seen from under the loggia (F) towards the cafeteria (E1) and kitchens (E2) (A. Guarino)

Figure 16: Conference room in courtyard III (H) (A. Guarino)

total cost of the intervention was $€ 915,870\left(€ 545.50 / \mathrm{m}^{2}\right)$, i.e. very low. ${ }^{4}$

Despite the training of three young people to manage the eco-museum and the undertaking that the municipality would support the start-up of the complex, the building has never been fully used for its intended purpose. After some roof improvements in 2019 and a restoration of the façade in 2020, part of it has been made over to a nursing association. 


\section{Casa di Teresa}

Named after its last owner, this building has two parts: the original west block from before 1950, and a block to the east added in 1955-1956 as the resident family increased (Fig. 17). In contrast to the tradition of building structurally independent modules, the $\mathrm{C}$-shaped extension had just three walls not actually connected to the pre-existing outer walls. This was probably to speed up construction and to reduce the amount of earth needed, and also due to a lack of structural knowledge.

The house is attributable to the "Italic" type (Conti 2004: 30 ), with the dwelling over the rooms linked to farm work: the bedrooms on the first floor were connected to each other and reached via a brick staircase and a ladder; the kitchen and the stable on the ground floor had independent accesses and imparted warmth to the rest of building. Toilets and fittings were absent. In recent times a concreteblock store with asbestos roofing had been added.

The massoni walls, built in direct contact with the ground and lacking proper foundations, are $80-85 \mathrm{~cm}$ thick at the base and $60-65 \mathrm{~cm}$ at the top. They were left exposed, except for the west bedroom, which was plastered and painted. The openings are small, to limit heat loss, surrounded by a margin of white plaster to reflect light into the interior.

In the intermediate floors, timber beams supported rough brick tiles. Downstairs the floors were of beaten earth, with brick flooring only in the kitchen. The double-pitched roof was insulated with a layer of earth and straw, covered with ceramic tiles.

Before the restoration, the building retained most of its original elements, but due to its abandonment and lack of maintenance since 1967, the incorrect dimensioning and anchoring of the walls, the absence of protective render, and the partial collapse of the roof, it was progressively deteriorating. The chimney had been seriously damaged by a fire and heavy-vehicle traffic. Unsound materials had been

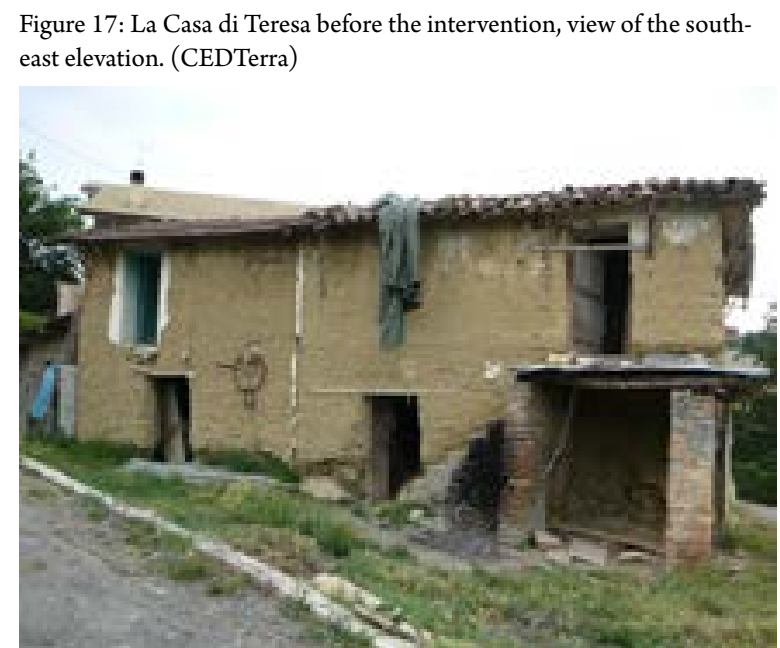

used to restore part of the walls, and weeds were growing at their base.

Casa di Teresa was purchased in 2008 by the municipality of Casalincontrada so as to save it from dereliction. Its location made it a perfect spot for a continuous, participatory rawearth workshop, set up on a self-build basis and open to experimentation: "In order to conceive the recovery of an earthen house, we must enter into the perspective of experimentation, of operating freely" (Conti 2016). From 2008 to 2015, workshops and events were organized in conjunction with the annual "Festa della Terra" (Earth Festival $)^{5}$, involving the local population together with experts, associations, artists, companies, universities, and building schools. More than 200 people took part (Fig. 18). The aim of the activities was to translate theory into experimental practice, interpreting knowledge derived from tradition and applying it to a restoration project.

Casa di Teresa has been given new functions, respecting the original character of the building and with "intelligent additions" (Conti 2008).

In order to ensure public use, an independent structure of perforated brick was built to accommodate toilets, the external staircase was rebuilt and an internal one was added, and electrical and heating systems, powered by photovoltaic cells, were installed. The outer area was reorganized and partly paved with bricks (Fig. 19).

The rehabilitation involved the use of earth, straw, wood, and fired brick, in accordance with traditional local techniques (Fig. 20).

Figure 18: "La finestrella", group photo from the September 2013 workshop. Architect Gianfranco Conti and Stefania Giardinelli in the centre (M. S. Bianco)

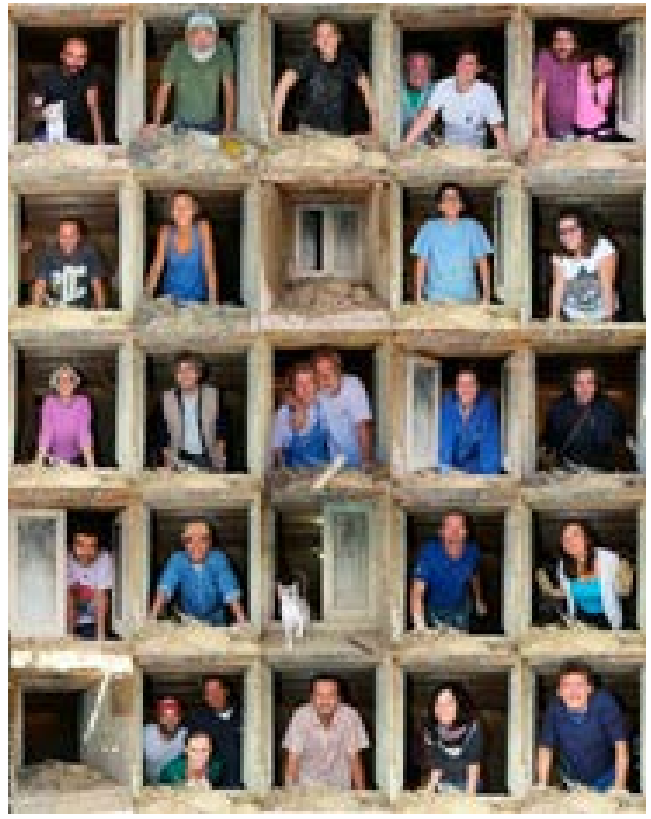



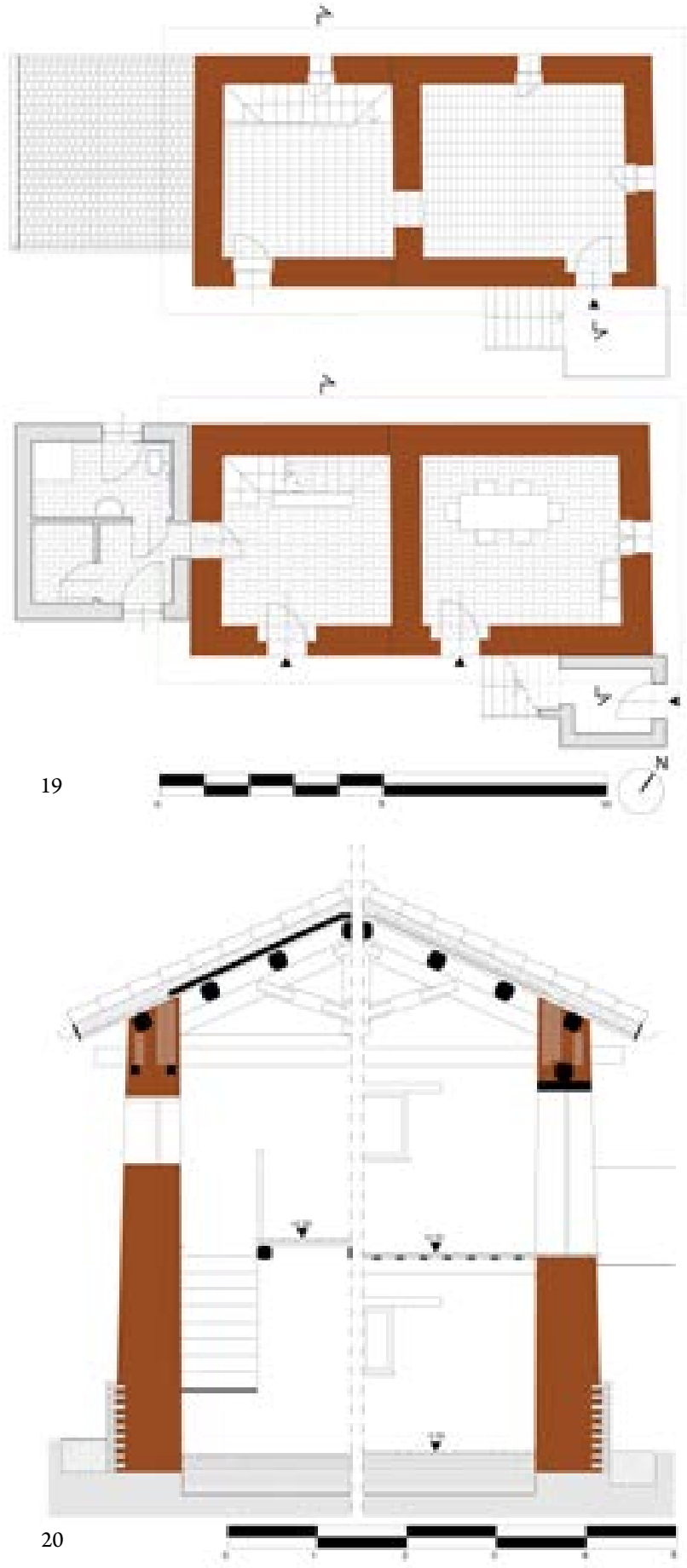

The inner surfaces of the walls were in good condition but loose parts had to be removed from the outer walls (Fig. 21). Cracks and gaps were consolidated and new massoni were laid, made from a mixture of earth, sand, water, straw, and pure gypsum. For every $5 \mathrm{~kg}$ of mud mixed with straw, one $20 \times 12 \mathrm{~cm}$ loaf-like brick was obtained. The bricks were left to cure overnight wrapped in straw and then laid (Figs. 22 and 23). A structural framework of twigs facilitated bonding with the existing masonry. The connection between the west and east blocks and the repair of the damaged chimney were executed using wooden frames filled with the massoni mixture, with wooden formwork. A wood bar was used to level the surface. Two tie-rods were fitted along the long side of the house.

The walls were entirely plastered, except in the west room, with a mixture of earth, sand, and straw; in the kitchen a lime plaster was applied. The window margins were repainted white using the lime in plaster residue from a selfbuilt lime kiln, subsequently covered with cocciopesto and converted into a baking oven.

A drain was dug around the perimeter and crawl spaces were made by digging $30 \mathrm{~cm}$ under the floors. A bakedbrick wall was erected along the façade bottom and the space in between was filled with the massoni mixture. The north and east corners were reinforced with buttresses.

The intermediate floors were rebuilt, maintaining the original position of the beams in the east room and rotating them in the west room so as to tie the walls together and to

Figure 19: Project plan of the ground floor (below) and first floor (above) of Teresa's House. In red are indicated the walls in massone Figure 20: West section (left) and east section (right): following an approach open to experimentation, different solutions were adopted in the construction of the ring beams and the covering of the roof. In red the massoni walls, in light red the raw earth bricks

Figure 21: Removal of plaster in the west first floor room (CEDTerra)

Figure 22: Massoni production cycle: reuse of earth, recycled from demolished parts and other collapsed buildings, making loaves and curing (CEDTerra)

Figure 23: Laying of massoni by workshop participants: they can be thrown with force, to allow the release of excess water, or laid on beds of dry straw and pressed to adhere and penetrate each pore (CEDTerra)
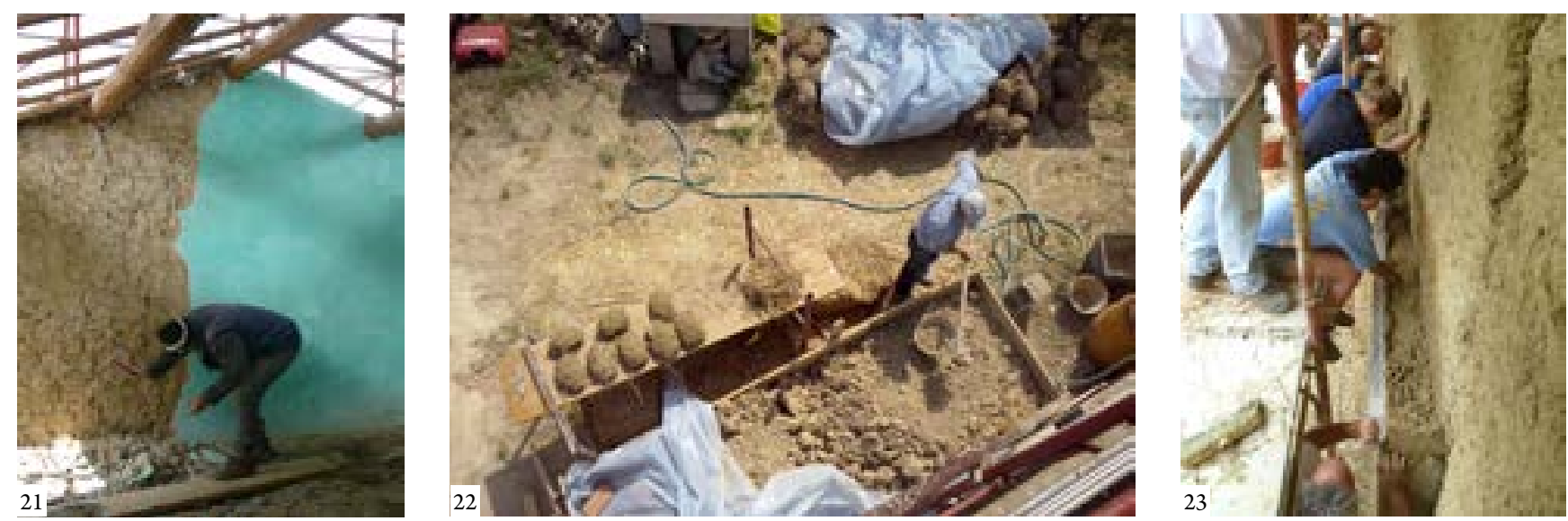

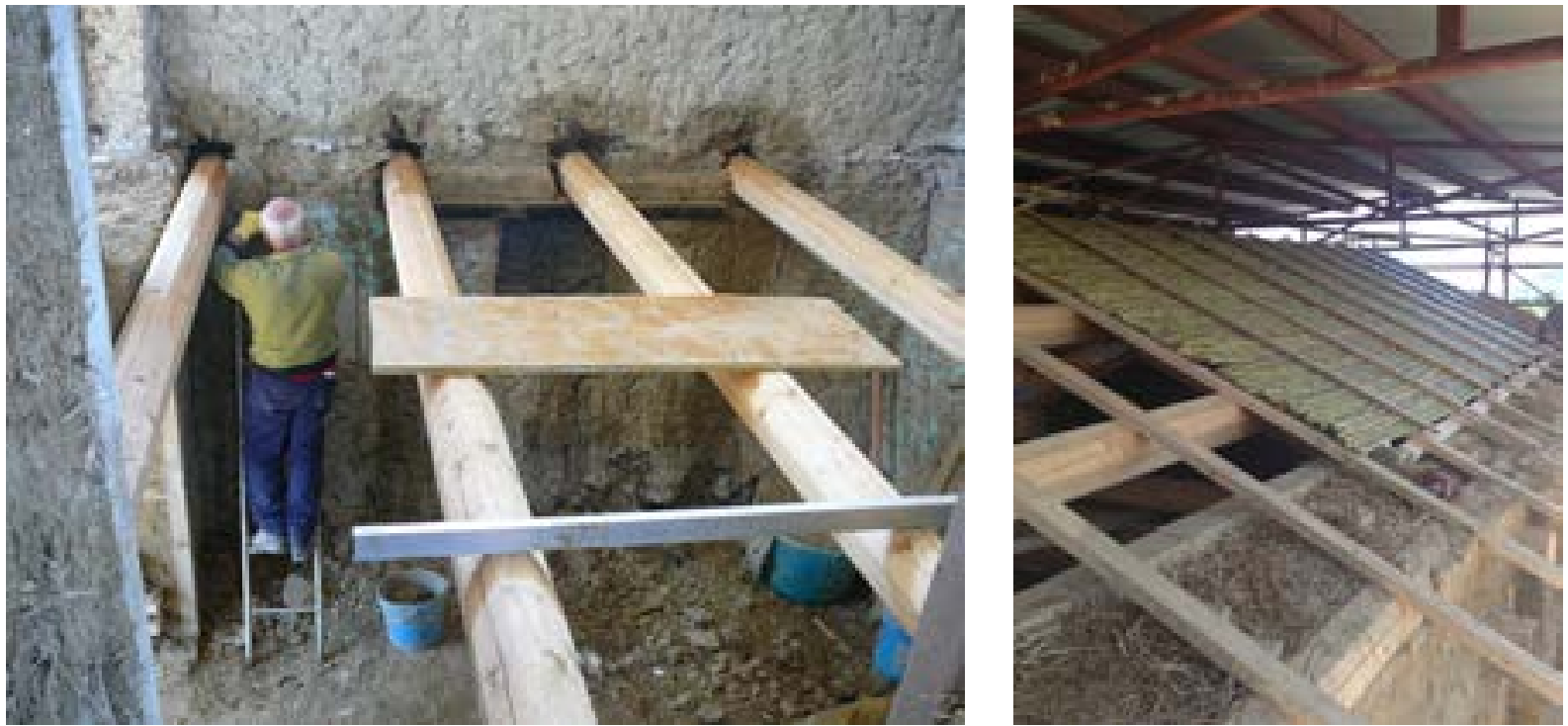

Figure 24: Laying the new beams in the west room (CEDTerra)

Figure 25: Laying of the laths made during the 2015 workshop (CEDTerra)

better distribute the loads (Fig. 24). Joists placed above the beams support the brick flooring.

Ring beams at the top of the walls distribute the loads of three trusses supporting the main beams and rafters. On the east half of the roof, laths covered with $10 \mathrm{~cm}$ of straw and earth were laid, and on the west half, wooden boards waterproofed with a membrane (Fig. 26). A layer of pressed

Figure 26: Casa di Teresa from the exterior

Figure 27: New internal staircase in the west portion. The tie-rod added during the renovation runs along the wall

Figure 28: Massoni walls left without plaster on first floor to the west
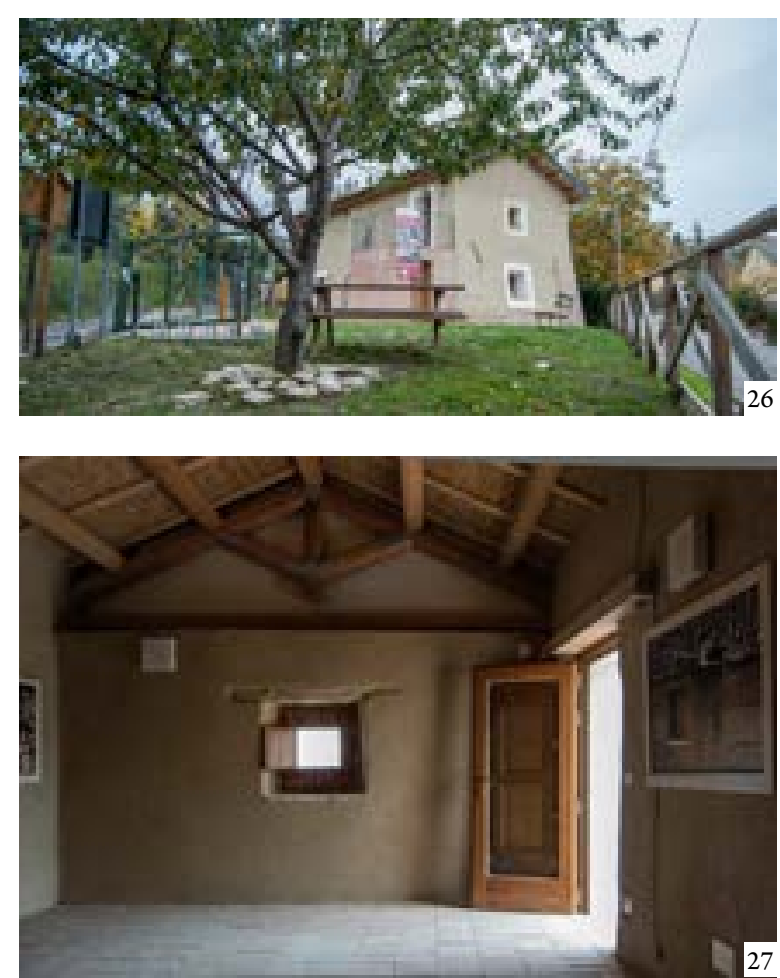

straw helps reduce heat loss. An OSB panel over the pressed straw supports the roof tiles.

The total cost of the intervention was $€ 116,220$ ( $€ 1,555 /$ $\mathrm{m}^{2}$ ), financed by regional funds. The waiting time for funding and the workshop construction method increased the duration of the work, which took place intermittently from 2008 to 2015 (Figs. 26-28).

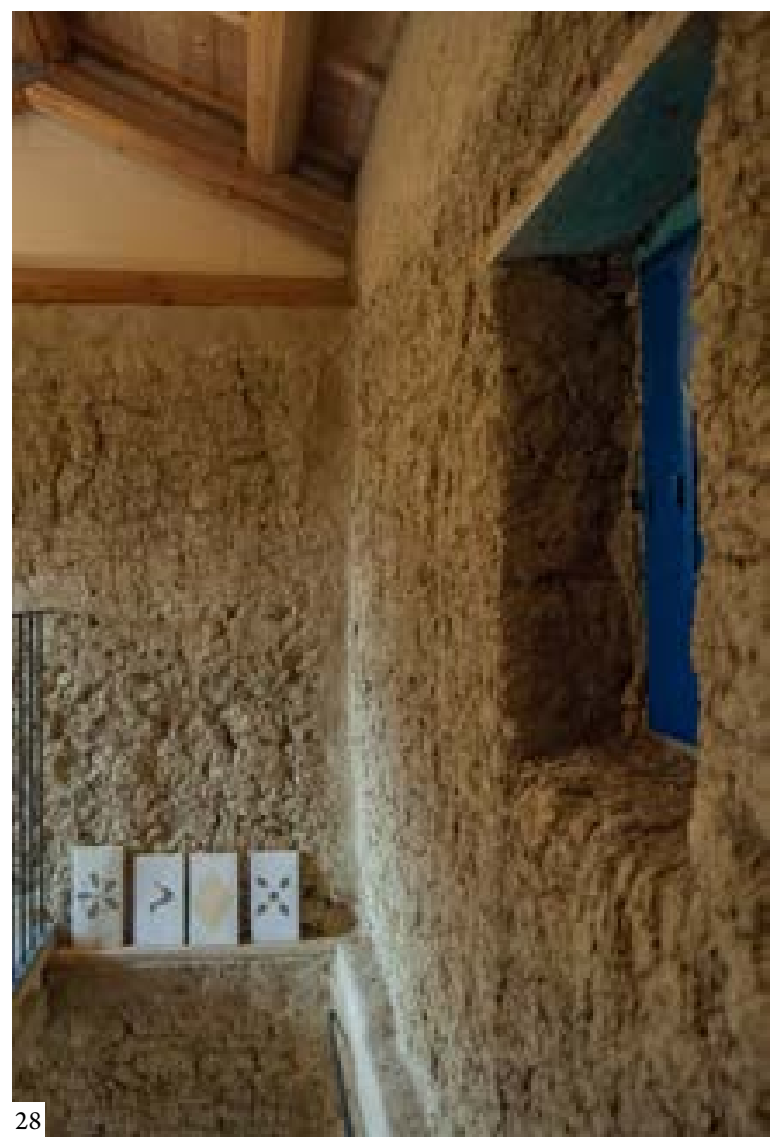




\section{Discussion}

Stimulated by the exhibitions Des architectures de terre (Centre Pompidou, Paris, 1982) and Case di terra. Memoria $e$ realtà, ${ }^{6}$ since the 1990 s there have been numerous local, regional and national initiatives involving earthen practitioners, academics, craftspeople and local authorities. In 1990 the Arch.Terra association was founded in Cagliari; in 1992 CEDTerra was established in Casalincontrada, coordinated by the Terrae-Onlus Association since 2000; in 1997 LabTerra was set up at the Cagliari University School of Architecture; in 2001 the Associazione Nazionale Città della Terra Cruda was founded, and it now encompasses forty municipalities in Sardinia, Abruzzo, Marche, Basilicata and Piedmont.

The Sardinia regional authorities have incorporated the experiences accumulated in recent years into manuals for the recovery and restoration of vernacular architecture, forming a body of rules and good practice liable to support local authorities (Sanna and Atzeni 2009; and Achenza 2009).

Numerous initiatives have also been launched in the Abruzzo academic community to disseminate good practices for work on earthen buildings (Forlani 2005).

The rehabilitations of Casa Fenu and Casa di Teresa were therefore part of a much wider picture, in a very active period in political and legislative terms. This section aims to portray these examples in context in order to understand the various factors that led to these restorations, and to evaluate their effects.

Villamassargia was the first Sardinian town to experiment with citizen consultation and participation in the drafting of its municipal urban plan ${ }^{7}$ of 2004 (updated in 2014), thanks to collaboration between the municipality, technicians and a multidisciplinary team of researchers, architects, and planners. One aim of the participatory approach was to generate awareness about the town's heritage value. With the mapping of abandoned buildings, it also showed that renovation could help meet housing needs without the provision of new buildings.

The Detailed Plan for the Historic Center (2003, updated in 2008) put further emphasis on the importance of Villamassargia as one of the few towns surviving the 14thand 15th-century destructions during the Aragonese domination of Sardinia (Medda 2008). Awareness of this could stimulate the preservation and recovery of traditional heritage, which represents about $79 \%$ of buildings, and enhance the identity of the historic center. Specific regulations were adopted to guide interventions.

Concurrently, grants were allocated by the regional authorities for rehabilitation work in historic city centers. 8 Through an Integrated Historic Center Program (based on Regional Law no. 29/98), public and private "diffuse maintenance" interventions were made (Pusceddu 2021).

The project to restore Casa di Teresa was also part of a process that has been going on for a number of years in Casalincontrada and the Abruzzo region.

In 1997 the province of Chieti catalogued 322 earthen houses in 15 municipalities. In the same year the regional law entitled "Provisions for the recovery and enhancement of tholos huts and earthen houses" (L.R. no. 17/97) was passed, implementing protective actions. Four municipalities, among them Casalincontrada, started a program of Albergo Diffuso hotels in 1999. ${ }^{9}$ In 2001, a regional law extended these incentives to earthen houses throughout the region, defining them as "historical testimony of the culture of Abruzzo" (Forlani 2011: 227).

As part of their top-down urban regeneration processes, the municipalities of Villamassargia and Casalincontrada saw a need to undertake the rehabilitation of traditional publicly owned buildings. Casa Fenu and Casa di Teresa were restored with the aim of providing good practice, a sort of real-life guideline to stimulate other bottom-up urban regeneration actions.

These tangible examples, as well as the efforts by the multidisciplinary team and the municipality to boost public awareness, did indeed contribute to the rehabilitation of 31 earthen buildings in Villamassargia in 2003-2015, and five in Casalincontrada in 2008-2019.

Such progress in a cultural context is slow but nevertheless significant, if we consider that raw-brick building heritage is almost exclusively in private hands in both regions. ${ }^{10}$

\section{Conclusion}

The rehabilitation of traditional heritage is now a global trend. The European Union is calling for a "renovation wave" in public and private buildings (European Commission 2019), with large investment in the energy refurbishment of existing buildings. The need to focus more on renovation than on new construction is even greater in areas of demographic decline such as Abruzzo and Sardinia with a surplus of housing stock.

While regions and municipalities seem to encourage a mindful recovery of traditional heritage through preservation laws and supporting actions, this is not always accompanied by a positive response from communities. The design of an earthen building, in restoration and even more so in new construction, is exceptional and remains confined to local experiences, a niche technology linked mainly to the revival of tradition or informal uses. 
The reasons for this are partly cultural: the fragmentation of the Italian cultural landscape results in inadequate cultural representation. A widespread awareness of the identity, historical, and architectural value of earthen buildings is still lacking. In this regard, Walter Secci reports a lack of appreciation of the value of ladiri buildings in Sardinia (Secci, interview). Gianfranco Conti notes that Abruzzo's earthen heritage still has a strong association with rural poverty (Conti, interview).

Changes in production traditions are another factor: Casa Fenu, for example, was built with exhausted agricultural soil used by farmers as building material; but the few remaining farms are now mechanized, soil is regenerated with chemical additives instead of lying fallow according to seasonal rhythms, and earth is no longer used for building houses because building materials are supplied industrially. The social set-up that used to be expressed through earthen architecture has disappeared or is on the way out (Germanà 2011:37-38).

Meanwhile, there are technical and regulatory impediments: raw-earth materials are not acknowledged as load-bearing in the national building code (as opposed to in other countries ${ }^{11}$ ), and obtaining a construction permit for an earthen building involves a long and expensive ad-hoc process in a branch of the national ministry. Another factor is the high seismic risk in most of the country. ${ }^{12}$

The lack of standardized criteria for assessing the performance of finished materials and controlling the quality of design and construction is a problem for owners and clients, and discourages potential investors (Bollini 2005; Mecca 2015: 21). This also affects small manufacturers: there are scarcely any professional ladiri producers in Sardinia, despite a great effort made to encourage certified production (Achenza 2010; Achenza et al. 2013). Even more complicated is the situation in Abruzzo, where it is almost impossible to envisage a process that might standardize the construction of massone buildings. The lack of a market in certified materials, in turn, leads to difficulties in carrying out interventions, especially in public tenders.

Alongside this, there is a lack of local-tradition-specific skills and know-how: a generational shift led to the abandonment of these techniques, no longer part of mainstream Italian cultural and architectural discourse, and the consequent non-transfer of building know-how. The renovation of an earthen building requires both meticulous planning and careful site management (Achenza, interview). The lack of demand is therefore matched by a lack of supply.

So there is a need for cultural and regulatory tools to propagate the qualities of exemplary "exceptional" interventions such as Casa Fenu and Casa di Teresa to common practice, especially in Sardinia where ladiri buildings are widespread.
To overcome mistrust, cultural investments are needed (Forlani 2011: 228). Such strategies may be enriched by local actions with identity value, well placed to take advantage of local production networks and technical know-how (Magnaghi 2010: 95,193; Watson 2019: 399). In this regard, the involvement of representatives of local communities was fundamental in Casalincontrada: interviews were carried out (Conti 2016), local master builders were invited to meetings, and young masons and the community were involved in numerous workshops.

Retrieving earthen building techniques would also involve identifying strategies for using this material efficiently, so that its contemporary value is recognized (Houben and Van Damme 2019: 38-39; Heringer 2020: 16, 18; Jenkins 2000; Laureano 2013: 298). Taking the positive evolution of timber construction as a reference, a comprehensive strategy to encourage the use of earth would be beneficial, including a renewed interest from the research community and skills development in research institutes; training for designers, craftspeople, and builders; and dissemination of good practice through communication platforms, awards, and international exhibitions (Gauzin-Müller 2021).

Alongside this, it would be good to restore the figure of the "homo faber" (Sennett 2008), a status that the architects Ignazio Garau and Gianfranco Conti aspired to and perhaps attained. They are examples of militating intellectuals, to quote Walter Secci's interview, capable of translating their knowledge into both written documents and built objects with social and spatial benefits.

\section{Dedication}

This article is dedicated to Ignazio, "A man of the earth, with the refined mind and curiosity of the intellectual, the firm hand of the artist - but also of the craftsman, who knows to touch and make things" (Pubusa 2018), who passed away a few months after our pleasant and stimulating meeting in his beloved Sardinia. Happy journey, Homo Faber. Thank you for your "act of courage", maestro.

\section{Interviews}

Ignazio Garau (30/5/2017-7/6/2017)

Gianfranco Conti(11-14/11/2017;4/2/2021;22/2/2021)

Walter Secci, vice-president of the Association City of Raw Earth and mayor of Villamassargia at the time Casa Fenu was restored $(2 / 6 / 2017 ; 11 / 2 / 2021)$

Maddalena Achenza, representative of ICOMOS-ISCEAH and director of LABterra $(5 / 7 / 2017 ; 26 / 2 / 2021)$ 
${ }^{1}$ A Survey of Rural Houses in Italy, carried out in 1934 by the Central Statistical Office (Shepis 1935), recorded 7,074 houses built in massone in Abruzzo, 3,343 of them in the province of Chieti. The current census records 806 buildings, 322 of them in the province of Chieti (Perotti 1999, Conti 1999).

${ }^{2}$ Garau was trained in earthen techniques from childhood on selfbuild sites and at seasonal workshops and on-site tile and brick kilns (Pubusa 2018). He engaged in urban, spatial and landscape planning, especially for the restoration of historic centers and villages in southern Sardinia. He was a member of the team that drew up the Villamassargia Municipality Urban Plan (2014) and the municipal building regulation (2015). Garau contributed to the creation of the Sardinian section of INU (the National Institute of Urban Planning). In Villamassargia he also supervised the restoration of the Church of Santa Maria della Neve.

${ }^{3}$ Because of his dedication to earthen building, he is considered the guardian of the massone's art: as president of the Terrae Association, he has coordinated the activities of the Permanent Documentation Center on Earthen Houses (CEDTerra) since 2000 and he promoted the 1997 census of earthen houses in the province of Chieti, subsequently extended to the entire Abruzzo region. The architects Stefania Giardinelli and Lucia Secondo also contributed to the rehabilitation of Casa Fenu.

${ }^{4}$ The renovation of Casa Fenu could be included in the category "Major renovations and restorations in historic centers": according to a 2006 report, the construction cost threshold for this category is $€ 1,530 / \mathrm{m}^{2}$ (Consiglio dell'Ordine degli Ingegneri della Provincia di Grosseto 2006).

${ }^{5}$ Cultural event promoted by the Municipality of Casalincontrada, organized every September since 1997.

${ }^{6}$ A 1985 exhibition held by the University of Chieti in collaboration with the Abruzzo region, linking the memory of earthen buildings in Abruzzo with those of Algeria, where earthen construction was still common. Currently viewable at the CEDTerra headquarters.

${ }^{7} 10 \%$ of the population was consulted in 2002 through a questionnaire. Besides a high level of appreciation for the town $(88 \%)$ and a willingness to go on living there (64\%), $71 \%$ of interviewees were also in favor of restoring the buildings in the historic center and preserving its heritage (La nuova Sardegna 2002).

${ }^{8}$ Four grants were provided between 2003 and 2015. In early 2021, the Città della Terra Association appealed to the regional authorities for a new allocation of resources to restart the rehabilitation process; this would also reactivate the supply chain of bricks, tiles, lime, timber, and stone, with opportunities for economic development among entrepreneurs and specialist craftspeople as well as helping revitalize the historic centers of southern Sardinia (Pusceddu 2021).

${ }^{9}$ Of the 27 planned restorations (including 13 abandoned earthen buildings), six have been carried out, of which two are not yet accessible.

${ }^{10}$ In Sardinia more than $90 \%$ of the 25,000 earthen buildings are privately owned (Pusceddu 2021).

${ }^{11}$ The first attempts to call for the establishment of technical standards for earthen buildings in Italy were in 2002, later included in the proposed bill of 2009 (Lion 2005), which also calls for a census and monitoring of earthen heritage, definition of the geographical areas where such building is possible, and the release of funds and incentives (http://casediterra. com/proposta-legge-schirru). Currently it is proposed that Italy may make use of an existing regulation, such as the German Lehmbau Regeln (for regulations in other countries, see Achenza 2017).

${ }^{12}$ Following the 2003 Seismic Standards, criteria for a new nationwide seismic classification were established. The process of restoring Casa Fenu was facilitated by the fact that at the time the project was approved, Sardinia was in the lowest-risk seismic zone. The situation is quite different in Abruzzo, 33\% of which is classified in the highest-risk seismic area, while Casalincontrada is classified as medium-risk.

\section{References $\mid$ Referencias $\mid$ Referências}

Achenza, Maddalena. 2009. La casa Fenu a Villamassargia. In Achenza, Maddalena; and Sanna, Ulrico (eds.), Il manuale tematico della terra cruda, Caratteri, Tecnologie e Buone pratiche, 86-91. Rome: DEI.

Achenza, Maddalena. 2010. Trasmissione delle conoscenze e insegnamento del know how. In Galdieri, Eugenio (ed.), Scritti sulla terra, 128-134. Saonara: Il Prato.

Achenza, Maddalena; and Meloni, Alessia (eds.). 2013. Standard di riferimento per la preparazione e la messa in opera dei mattoni in terra cruda. Rome: Progetto Cluster P.RE.MURA.

Achenza, Maddalena; and Chiri, Gianmarco. 2017. Imparare dal passato: costruzioni in terra in zona sismica. In: Bernardini, Gabriele; and Di Giuseppe, Elisa (eds.), Colloqui.AT.e 2017. Demolition or Reconstruction?, 228-240. Monfalcone: EdicomEdizioni.

Albanesi, Dante. 2012. Gianfranco Conti, architetto. Talenti e Territori. ScannoNaturaDoc, documentary television series. https://www. youtube.com/watch?v=tlbbhynd7d0 (consulted on 13/5/2021)

Baldacci, Osvaldo. 1958. L'ambiente geografico delle case in terra in Italia. Rivista geografica italiana, 65. Firenze: La Nuova Italia.

Bertagnin, Mauro. 1999. Architetture in terra cruda in Italia. Tipologie, tecnologie e culture costruttive. Monfalcone: Edicom Edizioni.

Bocci, Martina. 2018. A view of earth architecture between Europe and Brazil. Master thesis of Architecture for Sustainability Design. Torino: Politecnico di Torino. https://didattica.polito.it/laurea_magistrale/ architettura_progetto_sostenibile/en/presentation (consulted on $15 / 2 / 2021)$.

Bollini, Gaia. 2005. Dalla tutela alla nuova costruzione: la realtà normativa nazionale. In Bollini, Gaia (ed.), Atti del convegno Costruire in terra cruda oggi, 119-120. Monfalcone: Edicom Edizioni.

Conti, Gianfranco; Di Chiacchio, Antonio; Cicchetti, Maria; Fiadone, Franco; Gentile, Pierluigi; Morandi, Maurizio; and Forlani, Maria Cristina. 1999. Terra cruda. Insediamenti in provincia di Chieti. Penne: Cogestre Edizioni.

Conti, Gianfranco. 2004. Le case di terra: orgoglio e pregiudizio. In Conti, Gianfranco (ed.), Antologia della Terra Cruda. 1997-2004. Viaggio nella Terra Cruda in Italia, 23-37. Villamagna: Tinari.

Conti, Gianfranco. 2008. Laboratorio Terra. Sistema espositivo e informativo sulla tecnica tradizionale del massone in terra cruda. Relazione del progetto esecutivo. Casalincontrada.

Conti, Gianfranco. 2016. Il racconto della casa di Teresa. CEDTerra.https://www.facebook.com/58109899746/ videos/10155818524414747/ (consulted on 13/5/2021)

European Commission. 2019. The European Green Deal. Brussels. https://ec.europa.eu/info/strategy/priorities-2019-2024/europeangreen-deal it (consulted on 15/2/2021).

Forlani, Maria Cristina. 2005. Report sulle attività di ricerca di Fase I: Vulnerabilità dell'involucro delle costruzioni in crudo, criteri di valutazione del rischio nel progetto di conservazione: caso-studio sul patrimonio abruzzese. Pescara. http://www.taed.unifi.it/eah-management/main/ seminario16_05_06/I\%20report\%20Prin\%202005.pdf (consulted on $10 / 5 / 2021)$.

Forlani, Maria Cristina. 2011. Conservation strategies of Abruzzo's historical and cultural heritage. In Mecca, Saverio (ed.), Earth/Lands. Earthen Architecture of Southern Italy, 227-245. Pisa: ETS.

Garau, Ignazio. 2003. Comune di Villamassargia progetto di recupero e di ristrutturazione di un edificio "tradizionale" da destinare alla biblioteca, uffici comunali, spazi informagiovani e attività culturali. Relazione tecnica illustrativa. Villamassargia.

Garau, Ignazio. 2004. Stato dell'arte dell'architettura in terra cruda in Sardegna. In Conti, Gianfranco (ed.), Antologia della Terra Cruda. 
1997-2004. Viaggio nella Terra Cruda in Italia, 187-220. Villamagna: Tinari.

Garau, Ignazio. 2005. Esperienze di recupero in Sardegna: una chiave di lettura. In Bollini, Gaia (ed.), Atti del convegno Costruire in terra cruda oggi, 77-78. Monfalcone: Edicom Edizioni.

Gauzin-Müller, Dominique. 2021. Inspiring Regenerative Materials Architecture. CAS Regenerative Materials (online lecture)

Germanà, Maria Luisa. 2011. Earth as a building material between past and future. In Mecca, Saverio (ed.), Earth/Lands. Earthen Architecture of Southern Italy, 37-39. Pisa: ETS.

Heringer, Anna; Blair Howe, Lindsay; and Rauch, Martin. 2020. Upscaling Earth: Material, Process, Catalyst. Zürich: Gta Verlag.

Houben, Hugo; and Van Damme, Henri. 2019. Améliorer les performance de la construction en terre sans réduire ses atouts écologiques. In: Dethier, Jean (ed.), Habiter la terre. L'art de bâtir en terre crue: traditions, modernité et avenir, 38-39. Paris: Flammarion.

Jenkins. Tim N. 2000. Putting postmodernity into practice: endogenous development and the role of traditional cultures in the rural development of marginal regions. Ecological Economics, vol. 34, 3: 301-313.

La nuova sardegna. 2002. Quando il Puc è partecipato Villamassargia, per la prima volta nell'isola un piano regolatore sottoposto al vaglio preventivo da parte dei cittadini. Sassari, December 14 https://ricerca. gelocal.it/lanuovasardegna/archivio/lanuovasardegna/2002/12/14/ SU103.html (consulted on 12/2/2021)

Laureano, Pietro. 2013. La piramide rovesciata. Il modello dell'oasi per il pianeta terra. Torino: Bollati Boringheri.

Lion, Marco. 2005. Proposta per una normativa nazionale per la costruzione in terra cruda. In Bollini, Gaia (ed.), Atti del convegno Costruire in terra cruda oggi, 121-126. Monfalcone: Edicom Edizioni.

Magnaghi, Alberto. 2010. Il progetto locale. Verso la coscienza di luogo. Torino: Bollati Boringheri.

Mecca, Saverio. 2011 Earth/Lands. In Mecca, Saverio (ed.), Earth/Lands. Earthen Architecture of Southern Italy, 13-21. Pisa: ETS.

Medda, Antonello. 2008. Comune di Villamassargia. Piano Particolareggiato del Centro Storico.

Perotti, Antonio. 1999. Case in terra cruda. Diffusione degli insediamenti in Abruzzo. Regione Abruzzo: L’Aquila.

Pubusa Andrea. 2018. Ignazio Garau, mite costruttore di uguaglianza e bellezza. Democrazia oggi. http://www.democraziaoggi.it/?p=5349 (consulted on 1/3/2018)

Pusceddu, Enrico. 2021. Situazione edifici abbandonati in terra cruda in Sardegna. Città della terra cruda. Samassi. https://www.terracruda. org/it/news/situazione-edifici-abbandonati?fbclid=IwAR3Bsziylch_3 PZ7lw5Z2hAJJE8TgRXpLrZqHijsoXRtcsyPVtiJomEop7I (consulted on $12 / 2 / 21$ )

Sanna, Antonello; and Atzeni, Carlo (eds.). 2009. Architetture in terra cruda dei Campidani, del Cixerri e del Sarrabus. Roma: DEI.

Schepis Giovanni. 1935. Le case rurali nel mezzogiorno. Questioni Meridionali, 290-374. Napoli: EPSA.

Sennett, Richard. 2008. The Craftsman. London: Anne Lane.

Watson, Julia. 2009. LO-TEK. Design by radical indigenism. Cologne: Taschen.

\section{Biography $\mid$ Biografía | Biografia}

\section{Martina Bocci}

Martina graduated in Sustainable Architecture from Politecnico di Torino with a master's thesis on earth construction techniques in Europe and Brazil. She collaborates in a research project on the environmental impact assessment of low-tech buildings constructed mainly from natural materials. She is now pursuing a Ph.D. in Urban and Regional Development at the Inter-University Department of Urban and Regional Studies of Politecnico di Torino (DIST). Her research is focused on the role of the conservation and transmission of traditional construction techniques in local development. She is a co-founder of Accademia nel Cantiere (AnC), a nonprofit organization engaged in the design, researching and construction of sustainable architecture through the use of appropriate technologies and natural materials. 